\title{
Studies of Methylmalonyl Coenzyme A Carbonylmutase Activity in Methylmalonic Acidemia. I. Correlation of Clinical, Hepatic, and Fibroblast Data
}

\author{
GRANT MORROW III, ${ }^{18}$ MAURICE J. MAHONEY, CATHERINE MATHEWS, \\ AND JOYCE LEBOWITZ \\ Department of Pediatrics, University of Arizona College of Medicine, Tucson, Arizona, and Department of Human \\ Genetics, Yale University School of Medicine, New Haven, Connecticut, USA
}

\section{Extract}

Methylmalonyl-CoA carbonylmutase (mutase) activity was measured in fibroblast extracts from 15 patients with methylmalonic acidemia and in extracts of postmortem tissues from 6 of these children. Propionate oxidation and synthesis of 5'-deoxyadenosylcobalamin (AdoCbl, the vitamin $B_{12}$ coenzyme that is part of the mutase holoenzyme) were measured in intact fibroblasts. Mutase activity was low in the absence of added $\mathrm{AdoC} b \mathrm{l}$ in fibroblast extracts from both control subjects and patients. When the assay included supplemental AdoCbl, mutase activity increased in the control subjects (to $24.0 \mathrm{pmol}$ succinate $/ \mathrm{mg}$ protein $/ \mathrm{min}$ ) and in extracts from eight of the patients $(20.8 \mathrm{pmol} / \mathrm{mg}$ protein $/ \mathrm{min})$, but showed almost no change in extracts from the other seven patients $(0.16 \mathrm{pmol} / \mathrm{mg}$ protein $/ \mathrm{min})$. We have defined the eight fibroblast lines that showed normal mutase activity in the presence of AdoCbl as "responsive lines" and the other seven lines as "nonresponsive." In the liver or kidney extracts of postmortem tissues, mutase activity responded to AdoCbl supplementation if fibroblast mutase activity from that patient had responded, and failed to respond if fibroblast activity failed to respond. Mean propionate oxidation in intact fibroblasts was much higher in control lines than in either responsive or nonresponsive lines $\left(0.728\right.$ vs 0.097 vs 0.080 nmol $\mathrm{CO}_{2} / 10^{6}$ cells/hr, respectively). AdoCbl synthesis was normal $(0.27 \mathrm{pg}$ AdoChl/mg cells wet weight) in nonresponsive fibroblasts but was undetectable $(<0.005 \mathrm{pg} / \mathrm{mg}$ cells $)$ in the responsive lines. Thus, the deficiency of mutase activity in responsive fibroblast lines is due to the failure to synthesize significant amounts of AdoCbl, whereas the deficiency in nonresponsive lines is due to some other abnormality, presumably a defect in the mutase apoenzyme.

\section{Speculation}

Fibroblasts can be used to define whether patients with methylmalonic acidemia have an error of vitamin $B_{12}$ metabolism if both mutase activity and AdoCbl synthesis are measured. The response of fibroblast mutase activity to the addition of AdoCbl reflects accurately the responsiveness of the enzyme in other tissues of the body. If an error of vitamin $B_{12}$ metabolism is diagnosed with cultured fibroblasts, a prolonged trial of vitamin $B_{12}$ therapy is warranted in the patient to seek evidence of in vivo responsiveness and clinical benefit from vitamin therapy.

Human fibroblasts provide a valuable means for studying defects of propionate metabolism, inasmuch as propionate is degraded in vitro as in vivo. Propionate is activated and metabolized to succinyl-CoA through two intermediates, D- and Lmethylmalonyl-CoA (2). Failure to convert either isomer to succinyl-CoA results in the disease, methylmalonic acidemia
(MM-emia). With the exception of one patient (4) all MM-emia individuals exhibit an enzymatic block at the terminal, vitamin $\mathrm{B}_{12}$-dependent methylmalonyl-CoA carbonylmutase (mutase, EC 5.4.99.2) step, either as the result of apoenzyme failure or defective coenzyme synthesis. In the former situation, excretion of methylmalonic acid (MMA) does not decrease with massive doses of vitamin $B_{12}$, whereas in the latter, significant drops in urinary MMA are noted. Mahoney and coworkers (9) have demonstrated in tissue culture that fibroblasts from one patient who responds to vitamin $B_{12}$ therapy did not synthesize 5'-deoxyadenosylcobalamin coenzyme adequately. Correction of deficient mutase activity upon the addition of AdoCbl to a liver extract from one responsive patient has also been demonstrated, but no correction was found in liver extracts of three nonresponsive patients (10).

In the present study we have examined mutase activity and propionate oxidation in fibroblasts from 15 patients with MMemia and mutase activity in liver or kidney extracts from six of the patients. These data have then been correlated with AdoCbl synthesis in cultured fibroblasts from the same patients.

\section{METHODS}

Fibroblasts were cultured from skin explants and grown in Eagle's minimum essential medium containing $12 \%$ fetal calf serum as well as $100 \mathrm{U}$ penicillin and $100 \mu \mathrm{g}$ streptomycin $/ \mathrm{ml}$ or $100 \mu \mathrm{g}$ kanamycin $/ \mathrm{ml}$. Plastic flasks were maintained under an atmosphere of 5\% carbon dioxide in air. Roller bottles which had been gassed with $5 \% \mathrm{CO}_{2}$ in air and sealed were used when larger numbers of cells were required. When confluent, the cells were harvested from the flasks or roller bottles by adding a $0.125 \%$ trypsin-Versene mixture. Harvested fibroblasts were centrifuged at $500 \times g$ for $5 \mathrm{~min}$ and washed with $10 \mathrm{ml}$ buffered saline solution.

Cell lines were monitored for mycoplasma by standard culture techniques (3) as well as conversion of uridine to uracil (6). The presence of mycoplasmas did not have any measurable effect upon mutase activity in the extract experiments. Mycoplasma contamination increased the uptake of vitamin $B_{12}$ in culture but did not affect the intracellular conversion of the vitamin to the coenzymes. All experiments were performed on cultures passed fewer than 25 times.

\section{PROPIONATE OXIDATION}

Propionate oxidation was measured in intact cells which had been washed once and resuspended in Krebs-Ringer bicarbonate buffer containing $0.23 \%$ methyl cellulose as modified from the method of Morrow et al. (11). The reaction conditions are listed in Table 2. 


\section{MUTASE ACTIVITY}

The washed fibroblasts were resuspended in water $(0.1 \mathrm{ml}$ cells $/ 0.15 \mathrm{ml}$ water) and lysed by freeze-thawing five times in a $\mathrm{CO}_{2}$-acetone bath. The cell lysate was centrifuged at $2,000 \times g$ for $10 \mathrm{~min}$ at $10^{\circ}$, and the resulting supernatant was used to assay methylmalonyl-CoA carbonyl mutase activity. Extraction and quantitation of $\left[{ }^{14} \mathrm{C}\right]$ succinate were performed as described previously (10). Mutase activity in liver extracts was measured by the same technique $(10)$. The reaction mixture components are listed in Tables 3 and 4 .

\section{VITAMIN $B_{12}$ STUDIES}

Fibroblasts were grown in medium containing $\left[{ }^{57} \mathrm{Co}\right]$ hydroxocobalamin. After 4 or 5 days in culture, the cells were harvested and the intracellular cobalamins were extracted and separated as described previously (8). Radiolabeled AdoCbl and $\mathrm{MeCbl}$ were quantitated to measure the accumulation of newly synthesized coenzymes.

\section{MATERIALS}

Racemic $\left[{ }^{14} \mathrm{C}\right]$ methylmalonyl-CoA, a gift of Dr. Jonathan Brodie, was synthesized by the method of Trams and Brady (14). Dr. Robert Abeles of Brandeis University supplied the $5^{\prime}$-deoxyadenosylcobalamin coenzyme. $\left[{ }^{57} \mathrm{Co}\right]$ Cyanocobalamin, $100 \quad 170$ $\mu \mathrm{Ci} / \mu \mathrm{g}$ (Amersham-Searle), was converted quantitatively to $\left[{ }^{57} \mathrm{Co}\right]$ hydroxocobalamin as reported previously (8).

\section{RESULTS}

\section{CLINICAL DATA (TABLE I)}

Table 1 lists brief clinical descriptions of the 15 patients studied in this paper. Throughout the paper "responsive patients" refers to patients who respond in vivo to vitamin $\mathrm{B}_{12}$ therapy with a marked decrease of methylmalonate excretion in the urine. Responsive lines, on the other hand, are determined by in vitro studies using

Table 1. Clinical summary of methylmalonic acidemia patients

\begin{tabular}{|c|c|c|c|c|c|}
\hline $\begin{array}{l}\text { Pa- } \\
\text { tient }\end{array}$ & Sex & $\begin{array}{l}\text { In.vivo' } \\
B_{12} \\
\text { response }\end{array}$ & $\begin{array}{c}\text { In vitro }{ }^{2} \\
\text { response } \\
\text { to } \\
\text { AdoCbl }^{3}\end{array}$ & Clinical state & $\mathrm{Age}^{4}$ \\
\hline 1 & Female & - & - & Poor development & $31 \mathrm{mo}$ \\
\hline 2 & Female & - & - & Poor development & $23 \mathrm{mo}$ \\
\hline 3 & Male & - & - & Dead & $22 \mathrm{mo}$ \\
\hline 4 & Male & - & - & Dead & $15 \mathrm{mo}$ \\
\hline 5 & Female & Unknown & - & Dead & 8 days \\
\hline 6 & Male & - & - & Dead & $5 \mathrm{mo}$ \\
\hline 7 & Female & - & - & Dead & $18 \mathrm{mo}$ \\
\hline 8 & Female & + & + & Retarded & $51 / 2 \mathrm{yr}$ \\
\hline 9 & Male & + & + & Mildly retarded & $23 \mathrm{mo}$ \\
\hline 10 & Female & + & + & $\begin{array}{l}\text { Normal; diagnosed } \\
\text { in utero }\end{array}$ & $13 \mathrm{mo}$ \\
\hline 11 & Female & Unknown & + & Dead & $5 \mathrm{wk}$ \\
\hline 12 & Male & + & + & Normal & $31 / 2 \mathrm{yr}$ \\
\hline 13 & Male & - & + & Retarded & $6 \mathrm{yr}$ \\
\hline 14 & Female & - & + & Dead & $3 \mathrm{mo}$ \\
\hline 15 & Male & + & + & Normal & $7 \mathrm{yr}$ \\
\hline
\end{tabular}

${ }^{1} \mathrm{~A}$ positive response to $B_{12}$ therapy was a significantly decreased urinary excretion of methylmalonic acid.

${ }^{2}$ Response of methylmalonyl-CoA carbonylmutase activity in fibroblast extracts to the addition of AdoCbl; a positive response indicates an increase of mutase activity into the control range.

${ }^{3} 5^{\prime}$-Deoxyadenosylcobalamin.

${ }^{4}$ Age at death or, for living patients, age when fibroblast studies were completed.
AdoCbl and refer to lines which have normal mutase activity in the presence of excess AdoCbl. Seven patients have died whereas five of the remaining eight are developmentally abnormal. Patient 10 . diagnosed successfully prenatally (1), did not develop ketoacidosis because of early treatment. Patients 13 and 14 did not respond in vivo but are included in the responsive group because of in vitro studies with their fibroblasts. A more detailed clinical history of these two patients has been published by Kaye et al. (5). Adequate trials of intramuscular vitamin $B_{12}$ were not possible in patients 5 and 11 . The in vitro response column uses data obtained from the present study.

\section{PROPIONATE METABOLISM (TABLE 2)}

Oxidation of $\left[1-{ }^{14} \mathrm{C}\right]$ propionate to ${ }^{14} \mathrm{CO}_{2}$ was found to be defective in fibroblasts cultured from both nonresponsive as well as responsive patients. In only one experiment, using the cells of patient 14 , did propionate values fall into the control range. Two additional assays using patient 14 fell below the control range. Succinate metabolism was similar in all three groups. The present data for succinate oxidation are much lower than those already published (13). Although we have no satisfactory explanation, the differences may be due to the procedures used for harvesting and suspending cells with resultant differential membrane changes affecting uptake of succinate. When the ${ }^{14} \mathrm{CO}_{2}$ produced from propionate is related to that formed from succinate as a substrate, $(\mathrm{P} / \mathrm{S})$, no overlap is seen between patients and control subjects. The range of normal propionate oxidation is so broad that conclusions derived exclusively from its metabolism will be tenuous. Since succinate is a product distal to the block responsible for MM-emia, it serves as an internal control for the metabolic studies in intact cells. The $\mathrm{P} / \mathrm{S}$ ratios should be used when making interpretations regarding patients with defects in propionate or methylmalonate metabolism.

\section{LIVER MUTASE (TABLE 3)}

Liver samples from five patients were assayed from mutase activity. Only kidney tissue was available from patient 5 . Without coenzyme addition to the reaction mixture, mutase activity was either unmeasurable, i.e., $<0.05 \mathrm{pmol} / \mathrm{mg}$ protein $/ \mathrm{min}$ as in patients 3,4 , and 6 , or less than $10 \%$ of the lowest control value as in patients 5,11 , and 14 . Mutase activity in extracts from patients 11 and 14 fell into the normal range when supplemented with AdoCbl. The addition of AdoCbl to control liver extracts had only a small effect on mutase activity, indicating that $95 \%$ of the control liver mutase exists in the active holoenzyme form.

\section{FIBROBLAST MUTASE (TABLE 4)}

Table 4 lists mutase activity in fibroblast extracts. Mutase activity was absent or very low in extracts from patients' cells. Control values were also low, which indicated that most of the mutase in fibroblast extracts exists in the apoenzyme form rather than as the active holoenzyme. There is overlap of mutant and control ranges in unsupplemented reactions so that differentiation of the three groups cannot be made without adding AdoCbl. With the addition of AdoCbl, the mutant lines fall into two groups. In the first group (patients $1-7$ ), mutase activity remains very low. In the other group (patients $8-15$ ), there is an increase in mutase activity similar to the increase seen in control extracts. We refer to cell lines in this second group as responsive lines. No overlap existed in mutase activity of AdoCbl-supplemented extracts from nonresponsive and responsive fibroblasts.

\section{COBALAMIN METABOLISM (TABLE 5)}

Fibroblast lines from patients $l$ through 7 are classified as nonresponsive because of the in vitro failure of cell extracts to increase mutase activity with supplemental AdoCbl. In addition, all seven lines had defective in vitro propionate metabolism: of the six patients tested, all failed to respond to vitamin $\mathrm{B}_{12}$ in vivo, four (patients 3-6) had liver extracts in which mutase activity was 
Table 2. Propionate and succinate metabolism in intact fibroblasts from patients and control subjects ${ }^{1}$

\begin{tabular}{lccc}
\hline & ${ }^{14} \mathrm{CO}_{2}$ production, nmol/ $10^{6}$ cells/hr & \\
\cline { 2 - 3 } & $\begin{array}{c}{\left[1-^{14} \mathrm{C}\right]} \\
\text { Propionate } \\
\text { substrate }\end{array}$ & $\begin{array}{c}{\left[1,4-^{14} \mathrm{C}\right]} \\
\text { Succinate } \\
\text { substrate }\end{array}$ & $\begin{array}{c}\text { Propionate/ } \\
\text { succinate }\end{array}$ \\
\hline Nonresponsive & 0.080 & 0.171 & 0.7 \\
(patients 1-7) & $(0-0.203)^{2}$ & $(0.023-0.485)$ & $(0-1.7)$ \\
Responsive & 0.097 & 0.095 & 0.9 \\
(patients 8-15) & $(0-0.296)$ & $(0.035-0.186)$ & $(0-2.3)$ \\
13 Control subjects & 0.728 & 0.088 & 10.4 \\
& $(0.223-2.22)$ & $(0.0130 .204)$ & $(4.0-34.5)$
\end{tabular}

${ }^{1}$ The reaction mixture contained: $0.736 \mu \mathrm{mol}\left[1{ }^{14} \mathrm{C}\right]$ propionate $(\mathrm{sp}$ act $1.06 \mu \mathrm{Ci} / \mu \mathrm{mol}$ ) or $0.867 \mu \mathrm{mol}\left[1,4-{ }^{14} \mathrm{C}\right]$ succinate (sp act $0.894 \mu \mathrm{Ci}$ / $\mu \mathrm{mol}), 3.5 \mathrm{mg}$ methyl cellulose in a total volume of $1.5 \mathrm{ml} \mathrm{Krebs}$-Ringer bicarbonate $\mathrm{pH} 7.4$. Incubation time was $2 \mathrm{hr}$.

${ }^{2}$ Mean with range in parentheses.

Table 3. Methylmalonvl-CoA carbonylmutase activity in liver extracts ${ }^{1}$

\begin{tabular}{ccc}
\hline & \multicolumn{2}{c}{$\left[{ }^{14} \mathrm{C}\right]$ Succinate formed, $\mathrm{pmol} / \mathrm{mg}$ protein $/ \mathrm{min}$} \\
\cline { 2 - 3 } Patient & No AdoCbl added & AdoCbl added \\
\hline 3 & 0 & 0 \\
4 & 0 & 0.6 \\
$5^{2}$ & $0.5(30.4)$ & $4.0(63.5)$ \\
6 & 0 & 0 \\
11 & 2.6 & 53.9 \\
14 & 1.8 & 123 \\
Controls $^{3}$ & $54.5 ; n=13$ & $57.6 ; n=16$ \\
& $(29.9-156)$ & $(31.3-153)$ \\
\hline
\end{tabular}

${ }^{1}$ The incubation mixtures contained: $\left[{ }^{14} \mathrm{C}\right]$ methylmalonyl-CoA, 2.17 nmol (sp act $12.7 \mu \mathrm{Ci} / \mu \mathrm{mol}$ ): $375 \mathrm{nmol}$ Tris- $\mathrm{HCl}, \mathrm{pH} 7.30$; and 7.4 nmol AdoCbl. Protein extract (323 $964 \mu \mathrm{g}$ ) was added to initiate the incubation in a total volume of $180 \mu 1$. Incubation time was $10 \mathrm{~min}$. AdoCbl: deoxyadenosylcobalamin.

${ }^{2}$ Kidney extract, normal kidney values in parentheses.

${ }^{3}$ Mean plus range in parentheses.

nonresponsive, and all six of the lines tested synthesized AdoCbl normally in tissue culture.

Responsive fibroblast lines from patients 8 through 15 also demonstrated defective propionate metabolism in intact cells. Five of eight patients responded in vivo to vitamin $\mathrm{B}_{12}$, the two liver extracts demonstrated defective mutase activity without supplemental AdoCbl and normal activity with AdoCbl, and all eight lines were unable to synthesize $\mathrm{AdoCbl}$ although $\mathrm{MeCbl}$ accumulation and vitamin $B_{12}$ uptake were normal. These data are consistent with the theory that responsive patients with MM-emia are unable to produce adequate amounts of intracellular Ado$\mathrm{Cbl}$. As a result, mutase activity is decreased. Nonresponsive patients, on the other hand, are usually able to produce AdoCbl in adequate amounts but do not have normal mutase activity because of defective apoenzyme production. Two of the in vivo nonresponsive patients ( 13 and 14 ) demonstrated in vitro responsiveness of fibroblast mutase activity. Further studies are necessary to explain this apparent inconsistency.

\section{DISCUSSION}

Since the original description (12) of the initial two patients with methylmalonic acidemia, several variants have been described. The most significant finding is that some patients will respond to vitamin $B_{12}$ by decreasing MMA excretion when given vitamin
$\mathrm{B}_{12}$, whereas others will not. Prior to the present study, mutase activity had not been studied in various tissues from a single MM-emia patient. It had been shown that fibroblast extracts from a responsive patient exhibited increased mutase activity (13) when AdoCbl was added in vitro. This same line did not synthesize 5 -deoxyadenosylcobalamin normally (9). Liver extracts from another patient were noted to be responsive in vitro to supplemental AdoCbl (10). From the data presented here, it can be noted that when liver extracts are responsive to AdoCbl supplementation, then the fibroblast extracts are also responsive in any single patient. If liver extracts are nonresponsive, then fibroblasts react similarly. None of the eight responsive lines was able to synthesize

Table 4. Methylmalonyl-CoA carbonylmutase activity in fibroblast extracts ${ }^{\mathrm{i}}$

\begin{tabular}{lcc}
\hline \multicolumn{2}{c}{$\left[\begin{array}{c}\left.{ }^{14} \mathrm{C}\right] \text { Succinate- }{ }^{14} \mathrm{C} \text { formed, } \\
\text { pmol } / \mathrm{mg} \text { protein } / \mathrm{min}\end{array}\right.$} \\
\cline { 2 - 3 } & No AdoCbl added & AdoCbl added \\
\hline Nonresponsive & $0.06^{2 *} ; n=8$ & $0.31 ; n=12$ \\
(patients 1-7) & $(0-0.52)$ & $(0-0.87)$ \\
& $<0.01 ; n=6$ & $0.01 ; n=5$ \\
Responsive & $(0-0.01)$ & $(0-0.05)$ \\
(patients 8-15) & $0.61 ; n=13$ & $22.0 ; n=17$ \\
& $(0-2.14)$ & $(3.4-54.5)$ \\
& $0.05 ; n=7$ & $18.9 ; n=17$ \\
11 Control subjects & $(0-0.16)$ & $(2.9-40.4)$ \\
& $2.1 ; n=15$ & $27.0 ; n=24$ \\
& $(0.40-5.8)$ & $(3.4 \cdots 58.8)$ \\
& $1.38 ; n=10$ & $21.7 ; n=31$ \\
& $(0.19-4.90)$ & $(3.7-38.7)$ \\
\hline
\end{tabular}

${ }^{1}$ The incubation mixture contained: $\left[{ }^{14} \mathrm{C}\right]$ methylmalonyl-CoA, 2.17 $\mathrm{nmol}$ (sp act $12.7 \mu \mathrm{Ci} / \mu \mathrm{mol}$ ) or $0.50 \mathrm{nmol}$ (sp act $45.7 \mu \mathrm{Ci} / \mu \mathrm{mol} ; 450 \mathrm{nmol}$ Tris- $\mathrm{HCl}, \mathrm{pH} \mathrm{7.30}$; and $7.4 \mathrm{nmol} 5$ '-deoxyadenosylcobalamin (AdoCbl). Lysate protein $(185-585 \mu \mathrm{g})$ and water were added to a total volume of 170 $\mu 1$. Incubation time was $20 \mathrm{~min}$.

${ }^{2}$ Mean with range in parenthesis. The upper sets of data in each category were collected using methylmalonyl- $\mathrm{CoA}$ (sp act $12.7 \mu \mathrm{Ci} / \mu \mathrm{mol}$ ) and the lower values used sp act $45.7 \mu \mathrm{Ci} / \mu \mathrm{mol}$.

Table 5. Accumulation of $\left[{ }^{57} \mathrm{Co}\right] B_{12}$ in fibroblasts grown on media containing $\left[{ }^{57} \mathrm{Co}\right.$ hydroxocobalamin ${ }^{1}$

\begin{tabular}{cccc}
\hline Patient & AdoCbl $^{2}$ & $\mathrm{MeCbl}^{2}$ & ${\text { Total } \mathbf{B}_{12}{ }^{2}}^{2}$ \\
\hline 1 & 0.15 & 0.26 & 0.93 \\
2 & 0.18 & 1.36 & 3.43 \\
3 & 0.72 & 2.04 & 6.39 \\
4 & 0.12 & 0.72 & 3.04 \\
5 & 0.19 & 0.93 & 2.53 \\
6 & Normal & Normal & Normal \\
8 & $<0.005$ & 0.52 & 1.27 \\
9 & $<0.005$ & 2.02 & 6.38 \\
10 & $<0.005$ & 3.91 & 8.46 \\
11 & $<0.005$ & 0.35 & 1.55 \\
12 & $<0.005$ & 0.28 & 1.84 \\
13 & $<0.005$ & 0.30 & 1.28 \\
14 & $<0.005$ & 0.58 & 2.22 \\
15 & $<0.005$ & 0.72 & 2.86 \\
Control & $\bar{\chi}=0.37^{4}$ & $\bar{x}=0.59$ & $\bar{\chi}=2.21$ \\
Range & $(0.04-2.74)$ & $(0.14-4.15)$ & $(0.91-10.9)$ \\
& $n=30$ & $n=26$ & $n=49$ \\
\hline
\end{tabular}

${ }^{1}$ AdoCbl: 5'-deoxyadenosylcobalamin; MeCbl: methylcobalamin.

${ }^{2}$ Picograms of $\left[{ }^{57} \mathrm{Co}\right] \mathrm{B}_{12}$ per milligram of cells, wet weight.

${ }^{3}$ By method of Linnell et al. (7).

${ }^{4}$ Mean with range in parentheses. 
AdoCbl in vitro despite normal vitamin $B_{12}$ uptake and adequate synthesis of $\mathrm{MeCbl}$, whereas the nonresponsive fibroblast lines exhibited normal cobalamin metabolism. These data suggest that in vitro responsiveness is the result of correcting AdoCbl deficiency rather than overcoming a defective apoenzyme structure. In vitro studies of mutase activity were also consistent between liver and fibroblasts from the same patient; either both respond or both do not. In vivo studies are not completely consistent, however, as noted in patients 13 and 14 . The fibroblast extracts for these patients responded in vitro but the patients themselves did not respond in vivo. The reason for the unexpected in vitro response is not known. The important point from this inconsistency is that in no instance should clinical responses be the sole criteria used to diagnose a patient. If an error in vitamin $B_{12}$ metabolism is established by fibroblast studies as the cause of the methylmalonic acidemia, a prolonged trial (perhaps 3-4 weeks) of hydroxocobalamin at a high dose level $(2 \mathrm{mg} / 24 \mathrm{hr})$ should be undertaken before the patient is considered nonresponsive in vivo.

Using fibroblast data as the sole criteria for the diagnosis of MM-emia has certain limitations. As noted from Table 4, control data without supplemental $\mathrm{AdoC} b \mathrm{Cl}$ are quite similar to patient data. With the addition of AdoCbl, nonresponsive lines can be distinguished from control lines but responsive lines cannot. Quantitation of AdoCbl synthesis will separate responsive lines, which have deficient synthesis, from control lines with synthesis. Ideally, AdoCbl synthesis as well as mutase activity should be determined before a definite diagnosis is made in situations, such as that encountered in prenatal diagnosis, where only fibroblasts are available. Because most of the methylmalonyl-CoA carbonylmutase is present in the holoenzyme form, liver extracts, when available, can distinguish responsive from nonresponsive patients and from normal control subjects.

\section{SUMMARY}

Propionate oxidation, methylmalonyl-CoA carbonylmutase activity, and intracellular vitamin $B_{12}$ metabolism were studied in 15 fibroblast lines from methylmalonic acidemia patients. Propionate oxidation was low in all cell lines. The response of mutase activity in fibroblast extracts to the addition of the $B_{12}$ coenzyme, AdoCbl, showed a positive correlation in all cases with the response in liver or kidney extracts. In addition, the response was correlated with the ability of the fibroblasts to synthesize AdoCbl. Mutase activity increased to control levels with AdoCbl supplementation in cell lines that did not synthesize this coenzyme; activity failed to respond in lines that showed adequate AdoCbl synthesis. Thus, responsiveness of mutase activity in tissue extracts is a consequence of correcting a deficiency of the required coenzyme, AdoCbl.
Fibroblast extracts from two patients who had not responded to vitamin $B_{12}$ therapy did respond with an increase in mutase activity when AdoCbl was added; these fibroblasts also showed defective synthesis of AdoCbl. In order to obtain an in vivo response in patients that have an inborn error of vitamin $B_{12}$ metabolism, more vitamin $\mathrm{B}_{12}$ may be required that was previously considered to be an adequate dose.

\section{REFERENCES AND NOTES}

. Ampola, M. G., Mahoney, M. J., Nakamura, E., and Tanaka, K.: In utero treatment of methylmalonic acidemia with vitamin $\mathrm{B}_{12}$. Pediat. Res.. 8: 387 (1974).

2. Cannata, J. J. B., Focesi, A., Mazumder, R., Warner, R. C., and Ochoa, S.: Metabolism of propionic acid in animal tissues. XII. Properties of mammalian methylmalonyl coenzyme A mutase. J. Biol. Chem., 240: 3249 (1965).

3. Hayflick, L., and Standbridge, E.: Isolation and identification of mycoplasma from human clinical materials. Ann. N. Y. Acad. Sci., 143: 608 (1967).

4. Kang. E. S., Snodgrass, P. J., and Gerald, P. S.: Methylmalonyl coenzyme A racemase defect: another cause of methylmalonic aciduria. Pediat. Res., 6: 875 (1972).

5. Kaye, C. I., Morrow, G., and Nadler, H. L.: In vitro "responsive" methylmalonic acidemia: A new variant. J. Pediat., 85: 55 (1974).

6. Levine E M . Mycoplasma contamination of animal cell cultures: a simple, rapid detection method. Exp. Cell Res., 74: 99 (1972).

7. Linnell, J. C., Uhlendorf, B. W., and Mudd, S. H.: Personal communication.

8. Mahoney, M. J., and Rosenberg, L. E.: Synthesis of cobalamin coenzymes by human cells in tissue culture. J. Lab. Clin. Med., 78: 302 (1971).

9. Mahoney, M. J., Rosenberg, L. E., Mudd, S. H., and Uhlendorf, B. W. Defective metabolism of vitamin $B_{12}$ in fibroblasts from children with methyimalonicaciduria. Biochem. Biophys. Res. Commun., 44: 375 (1971).

10. Morrow, G., Barness, L. A., Cardinale, G. J., Abcles, R. H., and Flaks, J. G. Congenital methylmalonic acidemia: enzymatic evidence for two forms of the disease. Proc. Natl. Acad. Sci. U.S.A., 63: 191 (1969).

11. Morrow, G.. Mellman, W. J., Barness, L. A., and Dimitrov, N. V.: Propionate metabolism in cells cultured from a patient with methylmalonic acidemia Pediat. Res., 3: 217 (1969)

12. Oberholzer, V. G., Levin, B., Burgess, E. A., and Young. W. F.: Methylmatonic aciduria: An inborn error of metabolism leading to chronic metabolic acidosis Arch. Dis. Childhood, 42: 492 (1967).

13. Rosenberg, L. E., Lilljeqvist, A.-C., Hsia, Y. E., and Rosenbloom, F. M. Vitamin $B_{12}$ dependent methylmalonicaciduria: Defective $B_{12}$ metabolism in cilured fibroblasts. Biochem. Biophys. Res. Commun., 37: 607 (1969).

14. Trams, E. G., and Brady, R. O.: The synthesis of malonyl-C ${ }^{14}$ coenzyme A. J Amer. Chem. Soc., 82: 2972 (1960)

15. We thank the following individuals for supplying the cell lines used in these studies: line 2, Dr. F. J. van Sprang: line 5, Dr. Ronald Davidson: line 6. Dr. Stephen I. Goodman; line 7, Dr. Neil R. Buist: line 8, Dr. J. Fernandes; line 9. Dr Schuchmann: line 10. Dr. Mary G. Ampola: line 11. Dr. Harvey Mudd: Dr. Schuchmann: line 10, Dr. Mary G. Ampola: line 11 . Dr. Harvey Mudd: Caroline Murphy and Ms. Rosalie Blunden for cell culture and Ms. Anita Hart for cobalamin assays.

16. This research was supported in part by two National Foundation Grants and National Institutes of Health grants HD06575 and AM-12579.

7. Requests for reprints should be addressed to: G. Morrow, III, M.D., Departmen of Pediatrics. University of Arizona Medical Center. Tucson, Arizona 8572 (USA)

18. Accepted for publication April 8, 1975. 